\title{
Integration of Naqli and Aqli in Microbiology Teaching: Sharing the Experience
}

Nurul Azmawati Mohamed ${ }^{\mathrm{a}}$, Anuar Sani ${ }^{\mathrm{a}}$, Wan Shahida ${ }^{\mathrm{a}}$, Zarini Ismail ${ }^{\mathrm{a}}$, Ilina Isahak ${ }^{\mathrm{a}}$, Norazman Alias ${ }^{\mathrm{b}}$

${ }^{\mathrm{a}}$ Faculty of Medicine and Health Science, Universiti Sains Islam Malaysia

${ }^{\mathrm{b}}$ Faculty of Quranic and Sunnah Studies, Universiti Sains Islam Malaysia

\section{ABSTRACT}

Background: In line with Universiti Sains Islam Malaysia's (USIM) tagline 'Exploring Islamic Science, Spearheading Knowledge', we embarked on a new paradigm of teaching by integrating naqli components into the microbiology and immunology curriculum. The main objective of this integration was to enhance students' appreciation towards Islam and Science, so that they would become good Muslim doctors. The naqli components were delivered through various teaching and learning techniques such as lectures, seminars, and online assignments. Methods: A total of eighty year 3 students from Faculty of Medicine and Health Sciences, USIM were involved in this study. They were exposed to the new method of teaching for the whole academic year, session 2014/ 2015. The effectiveness of this program was evaluated through questionnaires, given at the end of academic session. Outcome: More than $90 \%$ students agreed that the integration were clearly delivered, relevant to the topics at hand and enhanced their knowledge. Most students $(>90 \%)$ preferred interactive lectures rather than students' initiated method such as seminar and speaker's corner. About two third of the students did not prefer online method. Moreover, $15.9 \%$ of them said the allotted time was insufficient and $46 \%$ agreed that there was inadequate resources in the library. Conclusions: The integration of naqli components into microbiology subject was favoured by students. However, it should be improved with allocation of more slots, upgrading of online system and increment of relevant library resources. Looking forward, we are convinced this is the way to go in producing holistic doctors equipped with necessary knowledge, both in aqli and naqli to further advance Medicine and Islam.

Keywords: medical, microbiology, integration, Islam, naqli

\section{Introduction}

The medical curriculum of the Faculty of Medicine and Health Sciences (USIM) was designed with the integration of Islamic input which aims at producing doctors who are able to practice medicine integrated with Islamic, moral and ethical values. Halaqah Studies and Fundamental Islamic Knowledge (FIK) courses such as History of Medicine in Islam, Science and Medicine in Quran and Sunnah, Akhlak and Tasawuf, Islamic Jurisprudence and Medical Ethics and Figh issues are taught to students during the pre-clinical and clinical phases (Jamilah et al 2014). In addition, Islamic elements are also incorporated into medical core subjects such as medicine, pathology and microbiology.

Corresponding author:

Nurul Azmawati Mohamed

Faculty of Medicine and Health Science,

Universiti Sains Islam Malaysia, Menara B,

Persiaran MPAJ, Jalan Pandan Utama,

55100 Kuala Lumpur.

Email:drnurul@usim.edu.my

Tel: (office) +60342892400

: (mobile) +60129646276

Fax: +60342892477

\section{Microbiology Course in FPSK, USIM}

Microbiology is taught in Year 3 (pre-clinical). It covers a vast area of study under the subheadings of immunology, infection control, bacteriology, virology, mycology and infectious diseases. The course has 6 credit hours and spreads over 2 semesters in Year 3. Immunology and infection control are introduced at the very beginning of semester one with the aim to provide basic knowledge of body defense mechanism particularly towards microorganism. Bacteriology, which is taught in the second half of semester one, focuses more on basic bacterial structure, pathogenicity, growth requirement and method of detection in the laboratory. Second semester starts with basic mycology and followed by virology.

Microbiology posting ends with infectious diseases topic that covers the whole-body systems: gastro-intestinal, respiratory, genitourinary, cardiovascular, skin and musculoskeletal and nervous system. A special seminar regarding microbiology and immunology-related prophetic food is also included in this course. Lecturers apply various teaching-learning methods that include lectures, practical, self-learning packages, problembased learning and seminars. Informal assessments are in the form of tutorials, online assignment, mock 
semester two examinations bring cumulative marks of $22.5 \%$ and $7.5 \%$ into the Second Professional Examination held at the end of year 3 .

\section{Integration of Naqli and Aqli in Microbiology Teaching Module}

Naqli knowledge is knowledge derived from Quran and Hadith or revealed knowledge, while Aqli knowledge is acquired knowledge (conventional knowledge) derived from human such as philosophical knowledge, natural sciences, medical sciences, humanities and many others.

The integration process of naqli and aqli in microbiology teaching is through embedment of Islamic principles and values in microbiology subject. The methods of integration can be divided into 4 categories or level called Mustawa. Level 1 or Mustawa 1 is called Al-Nusus (ayatisation) which means taking the verse as reference of Islamic values directly from the Quran and Hadith. Mustawa 2 is Al-Muqaranah (comparative) which means the differences and similarity approach between the revealed knowledge and conventional knowledge. The third Mustawa is called Al-Takyim (adaptation) which is a process of choosing, dividing and adapting the principle or values which is not contradicting to the values of Islam. Al-Tafaqquh (internalization) is combination and application of various discipline of knowledge to produced holistic curriculum.

Starting from session 2014/2015, naqli elements were introduced into the curriculum. Mustawa 3 (adaptation) and Mustawa 4 (internalisation) had been used in blending the naqli component into microbiology subject. The objective of this study was to evaluate students' response on this new teaching components and its method.

\section{Material and methods}

This study involved eighty year 3 students from the Faculty of Medicine and Health Sciences, Universiti Sains Islam Malaysia. They were exposed to a new way of teaching in relation to naqli and aqli integration. Students were given a set of questionnaire at the end of the academic session. Table 1 shows a summary of topics with example of naqli components and their method of delivery. Table 2 shows the list of questions. Students had to answer the questions by choosing either strongly disagree, disagree, agree or strongly agree. 'Agree and strongly agree' answers were added up to denote agreement to the statement.

Table 1: Conventional versus New Study Content

\begin{tabular}{|c|c|c|c|}
\hline Topic & Conventional Content & New Additional Naqli Content & Method \\
\hline Infection control & $\begin{array}{l}\text { - Sterilization } \\
\text { - Laboratory Safety } \\
\text { - Hand hygiene }\end{array}$ & $\begin{array}{l}\text { - } \quad \text { Cleanliness in Islam } \\
\text { - } \quad \text { Act of ablution and proper hand } \\
\text { hygiene technique } \\
\text { - } \quad \text { Fiqh of alcohol usage in hand rubs }\end{array}$ & Assignment \\
\hline Immunology & $\begin{array}{l}\text { - } \text { Basic immunology } \\
\text { - Tumor immunology } \\
\text { - Transplantation } \\
\text { - Immunisation }\end{array}$ & $\begin{array}{l}\text { - } \text { Fiqh of transplantation } \\
\text { - Immunisation from the Islamic } \\
\text { perspectives } \\
\text { - Concept of darurah and maqasid } \\
\text { syariah }\end{array}$ & Seminar \\
\hline Infectious diseases & $\begin{array}{l}\text { - Infections in every } \\
\text { organ systems }\end{array}$ & $\begin{array}{l}\text { - } \text { Prevention of infectious diseases } \\
\text { - } \text { Avcording to Islam: } \\
\text { - Circumcision } \\
\text { - } \text { Avoid area with epidemics } \\
\text { - Sunnah during sneezing } \\
\text { - Cleanliness }\end{array}$ & $\begin{array}{l}\text { Seminar } \\
\text { Lecture }\end{array}$ \\
\hline Prophetic food & - Honey & $\begin{array}{ll}\text { - } & \text { Goat's milk } \\
\text { - } & \text { Vinegar } \\
\text { - } & \text { Al-Habbah al-Sauda } \\
\text { - } & \text { Fruits: Dates, pomegranate }\end{array}$ & Seminar \\
\hline
\end{tabular}


Table 2: List of questions

\begin{tabular}{cl} 
No & Question \\
\hline 1 & The intergrations of Naqli and Aqli were clearly delivered. \\
3 & The Naqli inputs were relevant to the topics. \\
4 & The time allotted for Naqli input was sufficient. \\
5 & The integration of Naqli is best delivered using interactive lecture \\
6 & The integration of Naqli is best delivered using student presentation / seminar/ assignment \\
7 & The integration of Naqli is best delivered using online forum (GOALS) \\
8 & The integration of Naqli is best delivered using special lecture topic \\
9 & The integration of Naqli is best delivered using speaker's corner \\
10 & Library provides adequate reading material on Naqli (medical). \\
11 & The integration of Naqli should be assessed.
\end{tabular}

\section{Results}

Results showed that more than $90 \%$ students agreed that the integration were; clearly delivered, relevant to topics, and enhanced their knowledge. However, $15.9 \%$ of them said the time allotted was insufficient. Most students $(>90 \%)$ preferred interactive lecture rather than students' initiated method such as seminar and speaker's corner. Only $25.4 \%$ students preferred online learning method. Table 1 shows overall agree and strongly agree responses for each questions.

Table 1: Responses for Each Questions

\begin{tabular}{lc}
\hline Question & Agree \& strongly agree (\%) \\
\hline The intergrations of Naqli and Aqli were clearly delivered. & 96.8 \\
The Naqli inputs were relevant to the topics. & 99.0 \\
The Naqli inputs enhance my knowledge. & 96.9 \\
The time allotted for Naqli input was sufficient. & 84.1 \\
The integration of Naqli is best delivered using interactive lecture & 88.9 \\
The integration of Naqli is best delivered using student & 76.1 \\
presentation/seminar/ assignment & 25.4 \\
The integration of Naqli is best delivered using online forum & \\
(GOALS) & 65.0 \\
The integration of Naqli is best delivered using special lecture top- & \\
ic & 38.1 \\
The integration of Naqli is best delivered using speaker's corner & 46.0 \\
Library provides adequate reading material on Naqli (medical). & 71.4 \\
The integration of Naqli should be assessed. & \\
\hline
\end{tabular}




\section{DISCUSSION}

The integration of naqli and aqli in microbiology teaching is not only interesting but more importantly, it adds new dimension in triggering students to think and to reason why Islam advocates certain practices and banning others. This was agreed by Associate Professor Dr Tzar Mohd Nizam Khaitir from National University of Malaysia, the external examiner for Second Professional Examination in 2015, as written in his report to the Vice Chancellor "inclusion of Islamic principle and discussion on relevant issues from Islamic perspective are highly commendable" (Tzar 2015). From the lecturers' point of view, they found that students have been able to assimilate their textbook knowledge with Islamic input. This was evidenced by the ability to embrace hadith and quranic verses in their presentation, problem basedlearning and assignments.

Students preferred passive learning i.e. interactive lecture rather than students' initiated method such as seminar and speaker's corner. This finding was not alarming as many studies among medical and science students also showed similar results (Khane et al. 2014 \& Deo 2013). However, student-centered approach is important in teaching and learning processes as it encourages students to have more responsibility for their learning and is a process that relies heavily on professional confidence to 'let-go' of traditional teaching responsibilities (McCabe \& O'Connor 2014). Therefore, lecturers should find creative and innovative ways to make seminars more relevant and fun to students. Providing adequate audio-visual equipment for and giving incentive such as special reward to the best seminar may inspire students to deliver the best.

Feedback from the students were also encouraging where almost all students said that Islamic integration enhanced their knowledge. Nonetheless, they also gave some suggestions and ideas for improvement. Most of them felt that an expert in both naqli and aqli components should be available to facilitate and guide them while preparing and presenting their topics. For example, in Islamic International University of Malaysia (IIUM), the 'Islamic Input in Medical Program' was initiated and monitored by Professor Dr Omar Hassan Kasule, who is an expert in Islamic medicine (Ariff 2013).

Common to any new implementation, some shortcomings did crop up such as lack of experienced lecturers, lack of resources in the library, and time constraint in embedding this new component into an already hectic medical curriculum. A comprehensive training or workshop should be done periodically to give more exposures and ideas to the lecturers. Library should increase related online and offline resources to provide students with reliable references. It is also timely to re-look into the existing medical curriculum in order to achieve this newly introduced integration.

\section{CONCLUSION}

The integration of naqli components into microbiology subject was favored by students. Looking forward, we are convinced this is the way to go in producing holistic doctors equipped with necessary knowledge, both in aqli and naqli to further advance Medicine and Islam.

\section{REFERENCES}

1. Ariff O. Integrating Islamic Value in Medical teaching curriculum:IIUM Experience.

Bangladesh Journal of Medical Sciences. 2013. 12 (2): 117-120.

2. Jamilah J, Ahmad Najib A, Dzulkhairi MR, Ariff $\mathrm{HO}$, Nasri Ismail NM. Integration of Islamic Input in medical Curriculum- Universiti Sains Islam Malaysia (USIM) Experience. The International Medical Journal Malaysia. 2014. 13: 73:77.

3. Khane RS, Patil DY, Joshi AA. A Questionnaire Based Survey from First Year M.B.B.S. Students About Teaching Learning Methods of Physiology in Private Medical College. Paripex - Indian Journal Of Research. 2014. 2(3). 223-225

4. McCabe A, O'Connor U. Student-centred learning: the role and responsibility of the lecturer. Journal of Teaching in Higher Education. 2014. Vol 19, issue 4. 350-359.

5. SK Deo. Under graduate student feedback on teaching and evaluation method in clinical pharmacology. Journal of College of Medical Sciences-Nepal. 2013, Vol-9, No-3, 31-34.

6. Tzar MNK. External Examiner Report (Microbiology) for Second Professional Examination 2015. Faculty of Medicine and Health Sciences, University Sains Islam Malaysia. 2015. 